\title{
Catholic Women, Hidden Work, and Separate Spheres: The Columbian Catholic Congress of 1893-ADDENDUM
}

William S. Cossen

DOI: https://doi:10.1017/S1537781420000110. Published online by Cambridge University Press, 17 June 2020

The original online version of the article by Cossen $^{1}$ was published without the author's biographical paragraph. The paragraph should read as follows:

William S. Cossen is a member of the faculty of The Gwinnett School of Mathematics, Science, and Technology, and he received a PhD in History from The Pennsylvania State University. His first book, Making Catholic America: Religious Nationalism in the Gilded Age and Progressive Era, is under contract with Cornell University Press. His work has appeared previously in American Catholic Studies, American Nineteenth Century History, The Catholic Historical Review, The South Carolina Historical Magazine, and U.S. Catholic Historian.

In addition, the author's affiliation was not listed in the original article. It is as follows: The Gwinnett School of Mathematics, Science, and Technology; Decatur, GA, USA.

\footnotetext{
${ }^{1}$ William S. Cossen, "Catholic Women, Hidden Work, and Separate Spheres: The Columbian Catholic Congress of 1893," Journal of the Gilded Age and Progressive Era (Published online 17 June 2020). https:// doi:10.1017/S1537781420000110.

Cite this article: William S. Cossen (2021) "Catholic Women, Hidden Work, and Separate Spheres: The Columbian Catholic Congress of 1893-ADDENDUM," The Journal of the Gilded Age and Progressive Era 20, 478. https://doi.org/10.1017/S153778142100027X
} 